\title{
Attenuation of adhesion formation after cardiac surgery with a chymase inhibitor in a hamster model
}

\author{
Yoshiharu Soga, MD \\ Shinji Takai, PhD \\ Tadaaki Koyama, $\mathrm{MD}^{\mathrm{a}}$ \\ Yukiko Okamoto, MD, PhD \\ Tadashi Ikeda, MD, PhD ${ }^{a}$ \\ Kazunobu Nishimura, MD, $\mathrm{PhD}^{\mathrm{a}}$ \\ Mizuo Miyazaki, MD, PhD ${ }^{\mathrm{b}}$ \\ Masashi Komeda, MD, PhD
}

From the Department of Cardiovascular Surgery, ${ }^{\text {a }}$ Kyoto University Graduate School of Medicine, Kyoto, Japan, and the Department of Pharmacology, ${ }^{b}$ Osaka Medical College, Takatsuki city, Osaka, Japan.

Received for publication Sept 19, 2002; revisions requested Oct 31,2002 ; revisions received Nov 12, 2002; accepted for publication Jan 14, 2003

Address for reprints: Masashi Komeda, $\mathrm{MD}, \mathrm{PhD}$, Department of Cardiovascular Surgery, Kyoto University Graduate School of Medicine, 54 Shogoinkawahara-cho, Sakyo-ku, Kyoto, Japan 606-8507 (E-mail: masakom@kuhp.kyoto-u.ac.jp).

J Thorac Cardiovasc Surg 2004;127:72-8

$0022-5223 / \$ 30.00$

Copyright (C) 2004 by The American Association for Thoracic Surgery

doi:10.1016/S0022-5223(03)00697-4
Objective: Chymase is one of the inflammatory mediators and is released from mast cells, which are closely associated with adhesion formation. Chymase also activates transforming growth factor $\beta 1$, which promotes tissue fibrosis. However, the role of chymase in cardiac adhesion formation has not yet been elucidated. We have assessed whether a specific chymase inhibitor, Suc-Val-Pro-Phe ${ }^{\mathrm{p}}(\mathrm{OPh})_{2}$, prevents postoperative cardiac adhesions in hamsters.

Methods: In 66 hamsters the epicardium was abraded, and then either chymase inhibitor or placebo was injected into the left thoracic cavity, leaving the pericardium open. Cardiac chymase activity, the level of transforming growth factor $\beta 1$ in the pleural fluid, and the density of epicardial mast cells were measured 3 days postoperatively. The degree of adhesion formation was evaluated macroscopically and histologically 2 weeks postoperatively by using a grading score ranging from 0 (no adhesions) to 4 (severe adhesions).

Results: The cardiac chymase activity and level of transforming growth factor $\beta 1$ were lower in the chymase inhibitor-treated group compared with in the placebotreated group $(45.8 \pm 18.7 \mathrm{vs} 79.7 \pm 13.7 \mu \mathrm{U} / \mathrm{mg}$ protein $[P<.025]$ and $15.6 \pm$ $6.5 \mathrm{vs} 33.2 \pm 9.8 \mu \mathrm{g} / \mathrm{mL}[P<.01]$, respectively). The density of mast cells was higher in the placebo-treated group, and there was suppression to $60 \%$ of this value in the chymase inhibitor-treated group. The adhesion scores were lower in the chymase inhibitor-treated group compared with in the placebo-treated group $(1.3 \pm$ 1.3 vs $3.0 \pm 1.1, P<.01)$.

Conclusion: Use of a chymase inhibitor suppresses not only cardiac chymase activity but also the level of transforming growth factor $\beta 1$, and this results in a reduction in postoperative cardiac adhesion.

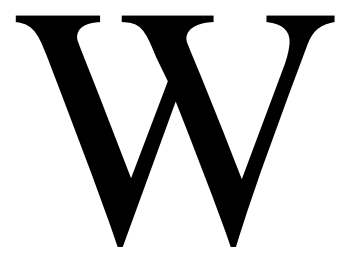

hen surgical reintervention is needed, the presence of existing postoperative adhesions remains a challenge, particularly in the field of cardiac surgery, in which the presence of cardiac adhesions increases the postoperative and reoperative surgical hazards. ${ }^{1-3}$ Although numerous materials and pharmacologic agents have been experimentally assessed in an effort to reduce the formation of adhesions, an ideal method has not yet been found.

The mechanism of adhesion formation is not fully understood, although mast cells, a type of inflammatory cell, are known to be closely associated with adhesion formation. ${ }^{4-7}$ The number of mast cells increases in the initial inflammatory stage, 
and inhibition of the activation and accumulation of mast cells with a mast cell stabilizer reduces intraperitoneal adhesion formation in a rat model. ${ }^{4}$ In addition, in mast cell-deficient mice intraperitoneal adhesion formation is less severe than in normal control mice. ${ }^{5}$ Mast cells release a large number of inflammatory mediators during adhesion formation, including histamine, serotonin, chemotactic factors, cytokines, and serine proteases. ${ }^{6,7}$ However, it is not clear which factor plays the major role.

Chymase is a chymotrypsin-like serine protease that is present in the secretory granules of mast cells. Recently, it has been found that chymase-containing serosal mast cells in rats express, secrete, and activate transforming growth factor $\beta 1$ (TGF- $\beta 1$ ) by means of a secretory mechanism in which chymase is coreleased as the TGF- $\beta 1$ activating enzyme. ${ }^{8}$ TGF- $\beta 1$ is known to be closely associated with adhesion formation, both in vitro 9 and in vivo. ${ }^{10,11}$ Therefore is seems likely that chymase plays a crucial role in adhesion formation and that the use of a chymase inhibitor could also inhibit the activation of TGF- $\beta 1$, with a resulting reduction in postoperative cardiac adhesion formation.

In the present study we have investigated whether a specific chymase inhibitor, Suc-Val-Pro-Phe ${ }^{\mathrm{p}}(\mathrm{OPh})_{2}$, can prevent postoperative cardiac adhesions in a hamster model.

\section{Materials and Methods}

Sixty-six mature male Syrian hamsters were used in the study. They were all 15 weeks of age and weighed between 140 and $200 \mathrm{~g}$. The study protocol had been approved by the Kyoto University Ethics Committee for Animal Research. All animals received humane care in compliance with the guidelines in the "Principles of Laboratory Animal Care" formulated by the National Society for Medical Research and the "Guide for the Care and Use of Laboratory Animals" prepared by the Institute of Laboratory Animal Resources, National Research Council, and published by the National Academy Press (revised 1996).

\section{Surgical Technique}

After endotracheal intubation, hamsters underwent general anesthesia with $1 \%$ to $2 \%$ isoflurane by using a volume-cycled ventilator for small animals (Rodent Ventilator, Harvard Apparatus 683). The chest was opened through a left thoracotomy, taking care to avoid injury to the underlying left lung. After pericardiotomy, the left side of the epicardium was abraded 100 times with gauze, and then a single 7-0 polypropylene suture (Prolene, Ethicon Inc) was placed in the epicardium. During the procedure, the operator was careful not to tear the fragile ventricular wall or injure the left anterior descending coronary artery. In the chymase inhibitor-treated group $(\mathrm{n}=33), 1 \mathrm{~mL}$ of $10 \mu \mathrm{mol} / \mathrm{L}$ Suc-ValPro-Phe $\mathrm{P}^{\mathrm{p}}(\mathrm{OPh})_{2}$ in normal saline was injected into the thoracic cavity. In a similar manner $1 \mathrm{~mL}$ of normal saline was introduced into the thoracic cavity in the placebo-treated group $(n=33)$. The pericardium was left open, and the chest was closed in 2 layers with 4-0 polypropylene sutures (Prolene, Ethicon Inc).

\section{Measurement of Cardiac Chymase Activity}

In 10 hamsters, 5 from the placebo-treated group and 5 from the chymase inhibitor-treated group, the whole heart was excised during general anesthesia 5 minutes after the end of the operation. In another 12 hamsters, 6 from each group, the hearts were excised 3 days postoperatively. These hearts were subject to rapid freezing and were then stored at $-80^{\circ} \mathrm{C}$ until use.

A tissue preparation method for the measurement of chymase activity has been described previously. ${ }^{12}$ The heart was minced and homogenized in 10 volumes (wt/vol) of $20 \mathrm{mmol} / \mathrm{L} \mathrm{Na}-$ phosphate buffer ( $\mathrm{pH}$ 7.4). The homogenate was then centrifuged at 10,000 rpm for 30 minutes, and the supernatant was discarded. This procedure was repeated twice. The pellets were then resuspended and homogenized in 5 volumes $(\mathrm{wt} / \mathrm{vol})$ of $10 \mathrm{mmol} / \mathrm{L}$ Na-phosphate buffer (pH 7.4) containing $2 \mathrm{~mol} / \mathrm{L} \mathrm{KCl}$ and $0.1 \%$ Nonidet P-40. The homogenate was stored overnight at $4{ }^{\circ} \mathrm{C}$ and then centrifuged at $10,000 \mathrm{rpm}$ for 30 minutes. Chymase activity was measured, as described previously, ${ }^{13}$ in the resultant supernatant, which was used as the tissue extract.

Aliquots $(20 \mu \mathrm{L})$ of the tissue extract were incubated for 10 minutes at $37^{\circ} \mathrm{C}$ with $4 \mathrm{mmol} / \mathrm{L}$ angiotensin $\mathrm{I}$ in a $150 \mathrm{mmol} / \mathrm{L}$ borax-borate buffer containing $5 \mathrm{mmol} / \mathrm{L}$ ethylenediamine tetraacetic acid, $8 \mathrm{mmol} / \mathrm{L}$ dipyridyl, and $0.77 \mathrm{mmol} / \mathrm{L}$ diisopropyl phosphorofluoridate at $\mathrm{pH} 8.5$ (resulting in a final incubation volume of $0.1 \mathrm{~mL}$ ). The reaction was terminated by the addition of $0.15 \mathrm{~mL}$ of $15 \%$ trichloroacetic acid. The samples were then centrifuged at $10,000 \mathrm{rpm}$ for 10 minutes. To perform a fluorometric quantification of the angiotensin II metabolite His-Leu, $10 \% o$-phthaldialdehyde (dissolved in neat methanol) was added to the supernatant under alkaline conditions, and then $6 \mathrm{~N} \mathrm{HCl}$ was added to stabilize the fluorescence for measurement at $340 \mathrm{~nm}$ of excitation and $455 \mathrm{~nm}$ of emission. A blank fluorometric assay was carried out after the addition of $0.5 \mathrm{mmol} / \mathrm{L}$ chymostatin (dimethylformamide solution). The protein concentration was measured with a bicinchoninic acid protein assay reagent (Pierce Chemical), with bovine serum albumin as the standard.

\section{Measurement of TGF- $\beta 1$ Level}

In 10 hamsters ( 5 from each group) TGF- $\beta 1$ was measured in an intrapleural wash sample that had been collected at 2 time points: after pericardiotomy but before adhesion creation and 3 days postoperatively. One milliliter of normal saline was trickled into the left thoracic cavity, and then this intrapleural wash sample was collected and frozen. The level of TGF- $\beta 1$ was quantified by using a TGF- $\beta 1$-specific enzyme-linked immunosorbent assay (R\&D Systems).

\section{Assessment of Adhesions}

In 22 hamsters (11 from each group) the degree of adhesion formation was assessed 2 weeks postoperatively. During general anesthesia, the chest was opened through a longitudinal right anterior thoracotomy, and the degree of adhesion between the heart and the chest wall was scored. The scores were graded blindly according to the modified classification of Hulka and colleagues ${ }^{14}$ : no adhesions, score 0 ; mild adhesions, score 1; localized moderate adhesions, score 2; moderate and extensive adhesions, score 3; and severe adhesions that were impossible to separate, score 4 . The 


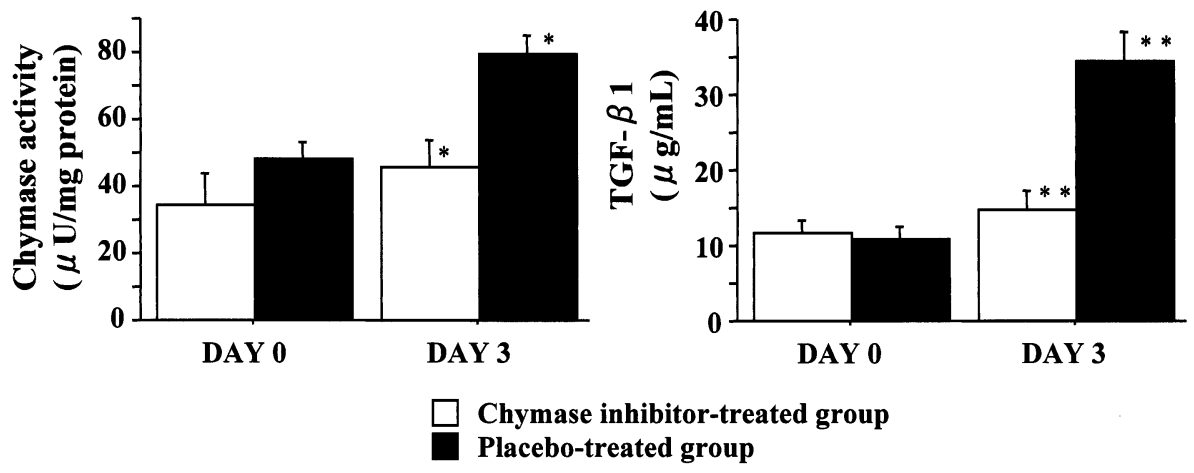

Figure 1. Left, The cardiac chymase activity in the chymase inhibitor-treated and the placebo-treated group 5 minutes after the end of the operation and 3 days postoperatively. ${ }^{*} P<.025$. Right, The level of TGF- $\beta 1$ in the pleural fluid in the chymase inhibitor-treated and the placebo-treated group perioperatively and 3 days postoperatively. ${ }^{* *} \boldsymbol{P}<.01$.

presence of adhesion formation between the heart and the left lung was also assessed.

\section{Histologic Study}

A histologic study was performed at 2 time points. In 12 hamsters (6 from each group) the whole heart was excised 3 days postoperatively before the development of adhesions, and the degree of mast cell accumulation was assessed. Mast cells around the epicardium were counted by a blinded observer using 3 horizontal cross-sections per specimen, one each from the apex, the midportion, and the base of the heart. In 22 hamsters (11 from each group) the entire heart with the adherent chest wall was excised 2 weeks postoperatively.

All the specimens were fixed in Carnoy solution, embedded in paraffin, and cut into 3- $\mu$ m-thick sections. The cross-sections were stained with hematoxylin and eosin and with toluidine blue to demonstrate the mast cells.

\section{Statistical Analysis}

The statistical analysis was carried out with StatView software version 5.0. Data are expressed as the mean $\pm 1 \mathrm{SD}$. A comparison in adhesion score, chymase activity, and the density of mast cells was performed by using the Wilcoxon test. The level of TGF- $\beta 1$ was evaluated by using the Wilcoxon test in a comparison between the groups and by using the Wilcoxon signed-rank test in a comparison between 2 time points in each group. Multiplicity of analysis was adjusted by using the Bonferroni method. The relative presence of adhesions between the heart and the lung was evaluated with the $\chi^{2}$ test.

\section{Results}

Preoperatively, there was no difference in body weight between the 2 groups. There were no wound complications in any of the hamsters up to 2 weeks postoperatively.

\section{Cardiac Chymase Activity}

The samples that were obtained 5 minutes postoperatively showed no significant difference in cardiac chymase activity between the 2 groups $(34.2 \pm 20.8 \mu \mathrm{U} / \mathrm{mg}$ protein in the chymase inhibitor-treated group and $48.2 \pm 11.1 \mu \mathrm{U} / \mathrm{mg}$ protein in the placebo-treated group). However, by the third postoperative day, the cardiac chymase activity in the placebotreated group $(79.7 \pm 13.7 \mu \mathrm{U} / \mathrm{mg}$ protein) was significantly higher than that found in the chymase inhibitor-treated group (45.8 $\pm 18.7 \mu \mathrm{U} / \mathrm{mg}$ protein; $P<.025$; Figure 1 , left).

\section{TGF- $\beta 1$ Level}

Samples obtained at the time of the operation showed no significant difference in the level of TGF- $\beta 1$ in the 2 groups $(11.7 \pm 3.8 \mu \mathrm{g} / \mathrm{mL}$ in the chymase inhibitor-treated group and $10.8 \pm 3.6 \mu \mathrm{g} / \mathrm{mL}$ in the placebo-treated group). However, 3 days postoperatively, the level of TGF- $\beta 1$ in the samples from the placebo-treated group $(33.2 \pm 9.8 \mu \mathrm{g} / \mathrm{mL})$ was significantly higher than that in the chymase inhibitortreated group $(15.6 \pm 6.5 \mu \mathrm{g} / \mathrm{mL} ; P<.01$; Figure 1 , right $)$.

\section{Assessment of Adhesions}

Representative photographs of the areas of adhesion are shown in Figure 2. In the placebo-treated group 64\% of hamsters had a score of 3 or 4 compared with the chymase inhibitor-treated group in which $64 \%$ had a score of 0 or 1 (Table 1). The average adhesion formation score in the chymase inhibitor-treated group $(1.3 \pm 1.3)$ was significantly lower than that found in the placebo-treated group $(3.0 \pm 1.1 ; P<.01)$. Adhesions between the heart and the adjacent left lung were found more frequently in the placebo-treated hamsters $(91 \%)$ compared with in the chymase inhibitor-treated hamsters $(27 \%$, Table 1$)$. This difference was also significant $(P<.01)$.

\section{Histologic Study}

Figure 3 shows a representative photograph of the microscopic findings of mast cells on the epicardium in a placebo- 


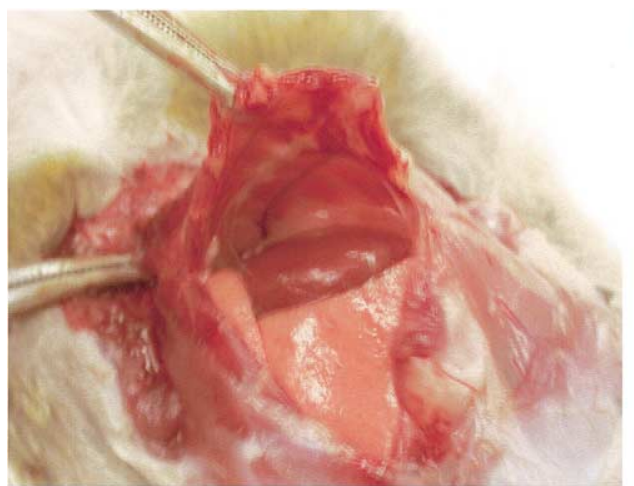

Score 0

(Chymase inhibitor-treated)

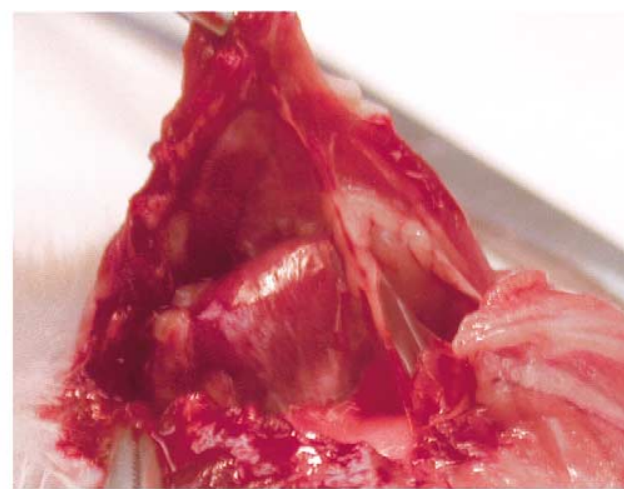

\section{Score 4 (Placebo-treated)}

Figure 2. Representative photographs of adherent areas in the placebo-treated and the chymase inhibitor-treated hamsters 2 weeks postoperatively.

TABLE 1. Macroscopic assessment of adhesion formation 2 weeks after the operation

\begin{tabular}{lllllr}
\hline & \multicolumn{5}{c}{ Scores } \\
\cline { 2 - 5 } Treatment & $\mathbf{0}$ & $\mathbf{1}$ & $\mathbf{2}$ & $\mathbf{3}$ & $\mathbf{4}$ \\
\hline Placebo & 0 & 1 & 3 & 2 & 5 \\
Chymase inhibitor & 4 & 3 & 2 & 1 & 1 \\
\hline \hline & \multicolumn{4}{c}{ Adhesions between the heart } \\
& \multicolumn{4}{c}{ and the lung } \\
\cline { 2 - 5 } Treatment & Yes (n) & No (n) \\
\hline Placebo & \multicolumn{1}{c}{10} & 1 \\
Chymase inhibitor & 3 & 8 \\
\hline
\end{tabular}

treated hamster 3 days postoperatively. Mast cells, the positive cells that have stained with toluidine blue, are seen to have accumulated on the epicardium with observable degranulation. In the placebo-treated group the density of mast cells was greater than in the chymase inhibitor-treated group, in which there were only $60 \%$ as many mast cells. (Table 2). However, this difference did not reach statistical significance.

Figure 4 shows a typical adherent lesion between the heart, the left lung, and the chest wall in a placebo-treated hamster 2 weeks postoperatively. This lesion has been stained with hematoxylin and eosin and with toluidine blue. An accumulation of mast cells was also seen in this lesion.

\section{Discussion}

The effect of postoperative adhesions, both on the surgical patient and on the risks during reoperation, has been well recognized in both cardiac and general surgery. In cardiac surgery adhesions between the sternum and the heart can

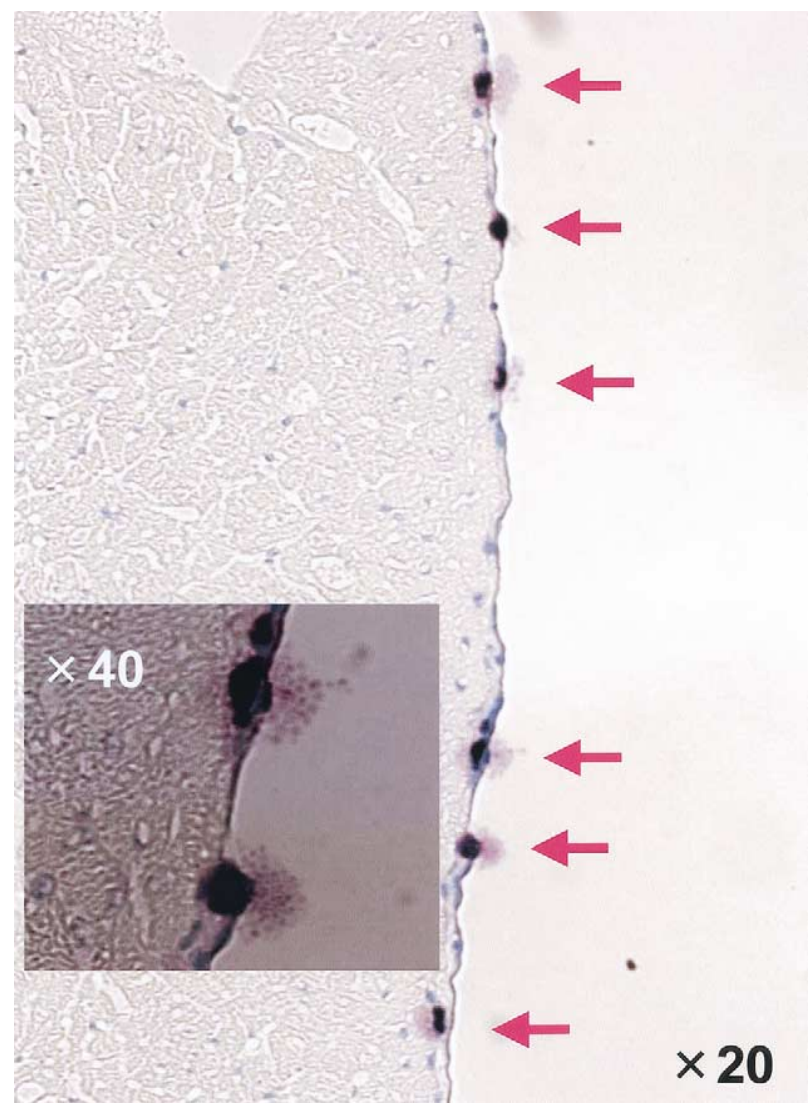

Figure 3. A section from the heart excised 3 days postoperatively and stained with toluidine blue. Arrows indicate the mast cells. Mast cells with marked degranulation are seen to be accumulating on the epicardium.

lead to catastrophic hemorrhage during resternotomy, ${ }^{1}$ and can cause right ventricular dysfunction ${ }^{2}$ and decreased coronary artery bypass graft patency. ${ }^{3}$ 
TABLE 2. Density of mast cells around the epicardium 3 days postoperatively

\begin{tabular}{lllll}
\hline & \multicolumn{4}{c}{ No. of mast cells } \\
\cline { 2 - 5 } Treatment & Base & Midportion & Apex & Average \\
\hline Placebo & $21 \pm 12$ & $23 \pm 13$ & $16 \pm 8$ & $20 \pm 10$ \\
Chymase inhibitor & $16 \pm 9$ & $13 \pm 5$ & $10 \pm 8$ & $12 \pm 6$
\end{tabular}

Average is defined as the total number of mast cells: (base + midportion + apex)/3. Data are expressed as the mean \pm 1 SD.

Closure of the pericardium has been recommended, ${ }^{15}$ but it is not possible to do this in all cases because pericardial closure might compress the heart, the bypass grafts, the extracardiac conduits, or other areas. In an attempt to prevent cardiac adhesions, there has been a recent trend toward the use of foreign physical barriers rather than pharmacologic agents. These barrier methods have included such techniques as an expanded polytetrafluoroethylene nonabsorbable sheet or a hyaluronic acid bioabsorbable membrane. However, although the expanded polytetrafluoroethylene sheet might obviate cardiac injury at resternotomy, it can form undesirable adhesions with the heart ${ }^{16}$ or the bypass graft. The clinical indication for the hyaluronic acid bioabsorbable membrane is currently restricted to abdominal operations. The ideal method to prevent cardiac adhesion has not yet been found.

In this study we have demonstrated for the first time that a specific chymase inhibitor, Suc-Val-Pro-Phe ${ }^{\mathrm{p}}(\mathrm{OPh})_{2}$, attenuates postoperative cardiac adhesion formation in vivo. When the chymase inhibitor was administered locally around the surgical lesion at the time of the operation, cardiac chymase activity, TGF- $\beta 1$ level, and the density of mast cells on the epicardium were all suppressed 3 days postoperatively (early phase). In addition, the adhesion formation scores were reduced 2 weeks postoperatively (late phase). Our results suggest that chymase produced from mast cells plays an important role in adhesion formation, although longer postoperative observation might be necessary in terms of clinical simulation.

In this study a single dose of a chymase inhibitor was effective in reducing postoperative cardiac adhesion formation. Oleksyszyn and Powers ${ }^{17}$ were the first to characterize the specific chymase inhibitor Suc-Val-Pro-Phe ${ }^{\mathrm{p}}(\mathrm{OPh})_{2}$, which was used in this study. The half-degradation time of the chymase inhibitor in human plasma is about 20 hours. Chymase exists in mast cell granules and is rapidly released through the process of degranulation when there is a strong stimulus, such as surgical intervention or injury. It then binds to the extracellular matrix and continues to function for several weeks. ${ }^{18}$ The chymase inhibitor is considered to bind irreversibly to chymase and then to reduce chymase function for several weeks. ${ }^{19}$ These findings suggest that an initial dose of a chymase inhibitor might be effective for several weeks. Indeed, we have previously found that chymase activity is significantly suppressed in vascular tissues for up to 3 months, even when a single dose of chymase inhibitor is administered during the operation at the same dose that was used in the present study. ${ }^{12,20}$ Therefore it is likely that cardiac chymase activity is inhibited by perioperative treatment with chymase inhibitor even 2 weeks postoperatively, as in the present study. No side effects of the chymase inhibitor were detected. It was administered locally and once during the operation, which might have minimized any side effects.

The present study is the first to demonstrate that the level of TGF- $\beta 1$ at the surgical site increases in parallel with the level of cardiac chymase activity after cardiac operations and that this increase is suppressed by perioperative treatment with a chymase inhibitor.

TGF- $\beta 1$ is considered to be related to adhesion formation $^{8-11,21}$ because it can induce intraperitoneal adhesion formation. ${ }^{10}$ In addition, antibodies to TGF- $\beta 1$ inhibit abdominal adhesions in the rat. ${ }^{11}$ TGF- $\beta$ enhances the formation of connective tissue and promotes tissue fibrosis and inflammatory cell infiltration. ${ }^{21}$ Recently, it has been found that chymase-containing rat serosal mast cells are capable of the expression, secretion, and activation of TGF- $\beta 1$ by means of a secretory mechanism in which the largely latent TGF- $\beta 1$ and the activating enzyme (chymase) are coreleased. ${ }^{8}$ Mature TGF- $\beta 1$ is stored in a largely latent form in the cytoplasmic secretory granules of the mast cells. Mast cell stimulation and degranulation leads to immediate secretion and activation of the largely latent TGF- $\beta 1{ }^{8}$ In combination with these previous findings, our results suggest that the prevention of cardiac adhesion formation by chymase inhibitor might be dependent on suppression of TGF- $\beta 1$ activation by chymase.

In the present study the density of mast cells on the epicardium 3 days postoperatively (early phase) was reduced in the chymase inhibitor-treated group compared with in the placebo-treated group (Table 2). Chymase has been reported to activate stem cell factor, a major cytokine regulator of mast cell growth and function. Stem cell factor also induces the accumulation of mast cells. ${ }^{22}$ Chymase is also known to induce the accumulation of other inflammatory cells, such as neutrophils and eosinophils, both of which are related to tissue remodeling. Therefore it is possible that a chymase inhibitor could suppress the additional accumulation of these inflammatory cells, which is induced by chymase, and that this would result in an attenuation of postoperative cardiac adhesions.

Chymase has been identified primarily as the major angiotensin II-forming enzyme in the human heart. ${ }^{23}$ It is known that hamster, monkey, and dog chymase all have the same chymase-dependent angiotensin II-generating system as in human subjects, although rat chymase uses a different 

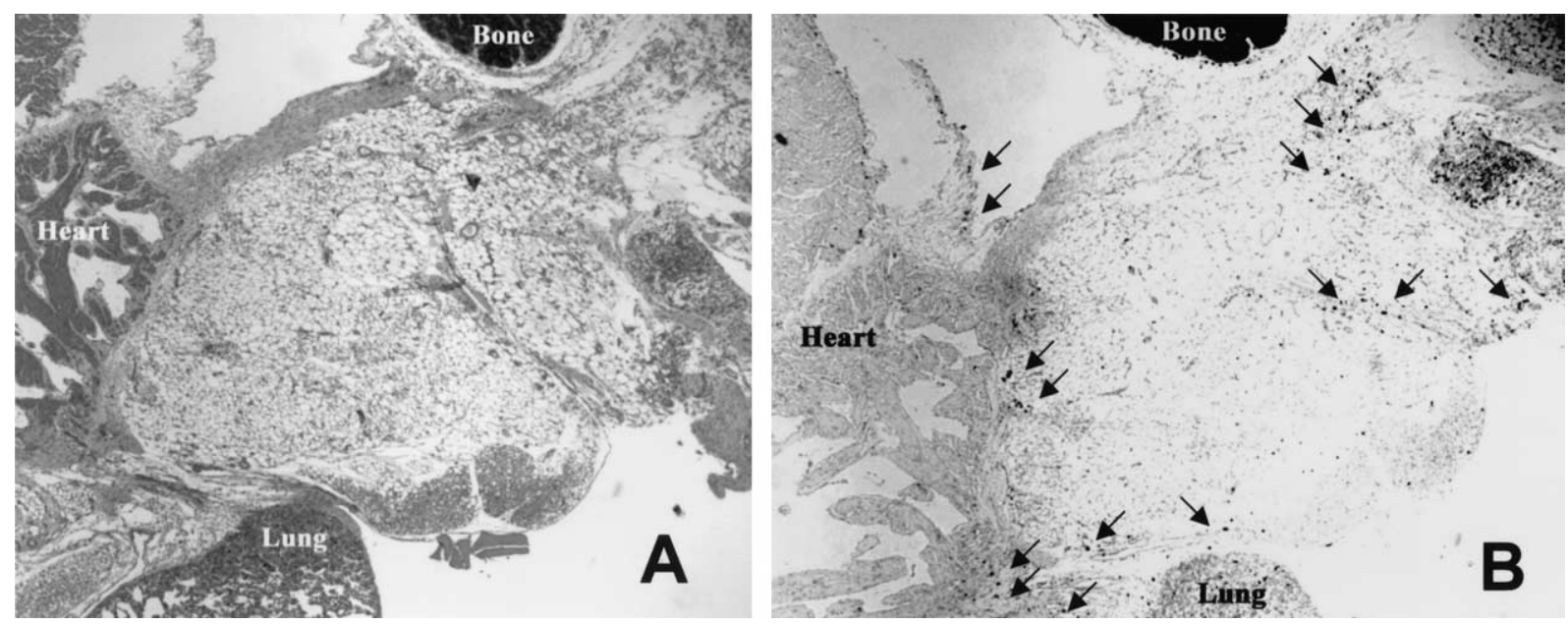

Figure 4. Sections from an adhesion between the heart, the lung, and the chest wall excised 2 weeks postoperatively and stained with hematoxylin and eosin (A) and with toluidine blue (B). (Original magnification $4 \times$.) Arrows indicate the mast cells.

system. ${ }^{24}$ In addition, hamster chymase has shown a quite similar character to human chymase from a viewpoint of the tolerance against serine protease inhibitors. ${ }^{25}$ For these reasons, hamsters were chosen as the model in this study.

\section{Limitations}

Despite perioperative treatment with a chymase inhibitor, in $2(18 \%)$ of 11 of the treated hamsters, moderate-to-severe adhesions were found. The most appropriate dose or delivery method needs to be verified, and in addition, the signal transduction between chymase and TGF- $\beta 1$ needs to be clarified.

\section{Conclusion}

We have demonstrated that a specific chymase inhibitor, Suc-Val-Pro-Phe ${ }^{\mathrm{p}}(\mathrm{OPh})_{2}$, reduces postoperative cardiac adhesion formation in a hamster model. Although further study is still necessary, this might be a useful technique for the attenuation of postoperative adhesions.

We thank Dr Oleksyszyn (Wroclaw Technical University, Poland) for the gift of Suc-Val-Pro-Phe ${ }^{\mathrm{p}}(\mathrm{OPh})_{2}$.

\section{References}

1. Loop FD. Catastrophic hemorrhage during sternal reentry. Ann Thorac Surg. 1984;37:271-2.

2. Bailey LL, Ze-jian L, Schulz E, Roost H, Yahiku P. A cause of right ventricular dysfunction after cardiac operations. J Thorac Cardiovasc Surg. 1984;87:539-42.

3. Urschel HC, Razzuk MA, Gardner M. Coronary artery bypass occlusion secondary to postcardiotomy syndrome. Ann Thorac Surg. 1976; 22:528-31.

4. Liebman SM, Langer JC, Marshall JS, Collins SM. Role of mast cells in peritoneal adhesion formation. Am J Surg. 1993;165:127-30.

5. Yao YL, Ishihara T, Takai S, Miyazaki M, Mita S. Association between the expression of mast cell chymase and intraperitoneal adhesion formation in mice. J Surg Res. 2000;92:40-4.

6. Ramos BF, Zhang Y, Jakchik BA, Qureshi R. Mast cells are critical for the production of leukotrienes responsible for neutrophils recruitment in immune complex-induced peritonitis in mice. J Immunol. 1991;147: 1636-41.

7. Das AM, Flower RJ, Perretti M. Eotaxin-induced eosinophil migration in the peritoneal cavity of ovalbumin-sensitized mice: mechanism of action. J Immunol. 1997;159:1466-73.

8. Rout UK, Saed GM, Diamond MP. Transforming growth factor- $\beta 1$ modulates expression of adhesion and cytoskeletal proteins in human peritoneal fibroblasts. Fertil Steril. 2002;78:154-61.

9. Lindstedt KA, Wang Y, Shiota N, Saarinen J, Hyytiainen M, Kokkonen JO, et al. Activation of paracrine TGF- $\beta 1$ signaling upon stimulation and degranulation of rat serosal mast cells: a novel function for chymase. FASEB J. 2001;15:1377-88.

10. Ghellai AM, Stucchi AF, Chegini N, Ma C, Andry CD, Kaseta JM, et al. Role of transforming growth factor-beta1 in peritonitis-induced adhesions. J Gastrointest Surg. 2000;3:316-23.

11. Lucas PA, Warejcka DJ, Young HE, Lee BY. Formation of abdominal adhesions is inhibited by antibodies to transforming growth factorbeta1. J Surg Res. 1996;65:135-8.

12. Takai S, Yuda A, Jin D, Nishimoto M, Sakaguchi M, Sasaki S, et al. Inhibition of chymase reduces vascular proliferation in dog grafted veins. FEBS Lett. 2000;467:141-4.

13. Takai S, Jin D, Sakaguchi M, Kirimura K, Miyazaki M. An orally active chymase inhibitor, $\mathrm{BCEAB}$, suppresses heart chymase activity in the hamster. Jpn J Pharmacol. 2001;86:124-6.

14. Hulka JF, Omran K, Berger GS. Classification of adnexal adhesions: a proposal and evaluation of its prognostic value. Fertil Steril. 1978;30: 661-5.

15. Rao V, Komeda M, Weisel RD, Cohen G, Borger MA, Daved TE. Should the pericardium be closed routinely after heart operations? Ann Thorac Surg. 1999;67:484-8.

16. Bunton RW, Xabregas AA, Miller AP. Pericardial closure after cardiac operations. J Thorac Cardiovasc Surg. 1990;100:99-107.

17. Oleksyszyn J, Powers JC. Irreversible inhibition of serine proteases by peptide derivatives of (alpha-aminoalkyl) phosphonate diphenyl esters. Biochemistry. 1991;30:485-93.

18. Craig SS, Schwartz LB. Human MCTC type of mast cell granule: the uncommon occurrence of discrete scrolls associated with focal absence of chymase. Lab Invest. 1990;63:581-5.

19. Oleksyszyn J, Powers JC. Amino acid and peptide phosphonate de- 
rivatives as specific inhibitor of serine peptidases. Methods Enzymol. 1994;244:423-41.

20. Tsunemi K, Takai S, Nishimoto M, Yuda A, Jin D, Sakaguchi M, et al. Lengthy suppression of vascular proliferation by a chymase inhibitor in dog grafted veins. J Thorac Cardiovasc Surg. 2002;124:621-5.

21. Taipale J, Lohi J, Saarinen J, Kovanen PT, Keski-Oja J. Human mast cell chymase and leukocyte elastase release latent transforming growth factor- $\beta 1$ from the extracellular matrix of cultured human epithelial and endothelial cells. J Biol Chem. 1995;270:4689-96.

22. Zhang S, Anderson DF, Bradding P, Coward WR, Baddeley SM,
MacLeod JDA, et al. Human mast cells express stem cell factor. J Pathol. 1998;186:59-66.

23. Urata H, Kinoshita A, Misono KS, Bumpus FM, Husain A. Identification of a highly specific chymase as the major angiotensin II-forming enzyme in the human heart. J Biol Chem. 1990;265:22348-57.

24. Miyazaki M, Takai S. Role of chymase on vascular proliferation [review]. J Renin Angiotensin Aldosteron Syst. 2001;1:23-6.

25. Takai S, Shiota N, Yamamoto D, Okunishi H, Miyazaki M. Purification and characterization of angiotensin II-generating chymase from hamster cheek pouch. Life Sci. 1996;58:591-7. 